\title{
A Power Case Study for Monocrystalline and Polycrystalline Solar Panels in Bursa City, Turkey
}

\author{
Ayşegül Taşçığlu, Onur Taşkın, and Ali Vardar \\ Department of Biosystems Engineering, Faculty of Agriculture, Uludag University, 16059 Bursa, Turkey \\ Correspondence should be addressed to Ali Vardar; dravardar@uludag.edu.tr
}

Received 23 January 2016; Revised 8 February 2016; Accepted 18 February 2016

Academic Editor: Vishal Mehta

Copyright (C) 2016 Ayşegül Taşçığlu et al. This is an open access article distributed under the Creative Commons Attribution License, which permits unrestricted use, distribution, and reproduction in any medium, provided the original work is properly cited.

\begin{abstract}
It was intended to reveal the time dependent power generation under different loads for two different solar panels under the conditions of Bursa province in between August 19 and 25, 2014. The testing sets include solar panels, inverter, multimeter, accumulator, regulator, pyranometer, pyrheliometer, temperature sensor, and datalogger. The efficiency of monocrystalline and polycrystalline solar panels was calculated depending on the climatic data's measurements. As the result of the study, the average performances of monocrystalline and polycrystalline panels are 42.06 and $39.80 \mathrm{Wh}$, respectively. It was seen that $87.14 \mathrm{~W}$ instantaneous power could be obtained from monocrystalline solar panel and that $80.17 \mathrm{~W}$ instantaneous power could be obtained from polycrystalline solar panel under maximum total radiation $\left(1001.13 \mathrm{~W} / \mathrm{m}^{2}\right)$. Within this frame, it was determined that monocrystalline solar panel is able to operate more efficiently under the conditions of Bursa compared to polycrystalline solar panel. When the multivariate correlations coefficients were examined statistically, a significant relationship in positive direction was detected between total and direct radiation and ambient temperature on energy generation from monocrystalline and polycrystalline panel.
\end{abstract}

\section{Introduction}

Today, one of the most significant requirements of developed and developing countries is energy. Even if there are various methods of energy production and consumption, all the countries require cheap, large, and clean energy sources [1]. As the fossil fuels will be consumed after a specific period and as their production is very expensive, it becomes obligatory to determine alternative energy sources and to benefit from these sources with high efficiency. Moreover, the use of energy sources which cannot be renewed at a large extent had significantly increased the environmental problems. Thus, tendency towards renewable energy sources with low environmental effects is advantageous in all aspects [2]. Renewable energy sources are defined as energy flows which are replaced at the same speed as they are used. All renewable energy sources on Earth arise from the effect of solar radiation which can be directly or indirectly converted to energy by using different technologies.

Even if it is the most expensive renewable energy technology, "photovoltaic" technology is the easiest energy technology in respect of design and installation. But its main superiority arises from the fact that it is an environment friendly technology with low maintenance cost [3]. Besides these, photovoltaic systems are also modular. In other words, they can be assembled anywhere required. In case of increase of requirement, new photovoltaic models can be easily added to the system in a short while. This is not in subject for other energy production systems. In particular the photovoltaic systems that are installed close to end users decrease the requirement for transmission and distribution devices and increase the reliability of local electric service.

Crystalline silicon offers an improved efficiency when compared to amorphous silicon while still using only a small amount of material [4]. Silicon has several advantages such as abundance on Earth, low contamination rate, high durability, and the wide experience of the microelectronics industry. The most widely used silicon cells in manufacturing are monocrystalline and polycrystalline, although many other technologies have been developed [5]. In the first commercial solar panels, monocrystalline structured silicon had been 
used which was being enlarged by the crystal pulling method. In this technique, which is still the commonly used method in photovoltaic industry, first pure silicon is obtained through various chemical and thermal reactions of silicon oxide in arc furnaces. And then, a monocrystalline structured silicon piece is dipped in the silicon melt. When the core is removed from the melt, the cooling silicon melt becomes piled all around the core. This silicon is divided into slices after getting chunk. This happens in two phases. First the pile is cut in the form of rectangle blocks. And then these blocks are separated to slices and processed in the form of panel. The high amount of material loss during production is the disadvantage of these cells. They are produced with a thickness of about $0.5 \mathrm{~mm}$. Their color is dark blue, and their approximate weight is less than 10 gr. Polycrystalline silicon production technologies are easier. The commonly used method in production is the casting method. In polycrystalline silicon, the starting material is prepared as in the monocrystalline silicon. The required purity degree is also similar. The melted silicon with a semiconductor quality is casted into the moulds and left for cooling. And then the obtained blocks are cut in square form. The cost of solar panels obtained from materials produced by this technology is low compared to their efficiency [6].

Solar panels are nonlinear energy sources, and the operation points of the system also change along with the change in weather conditions [7]. Thus, the current/voltage values, power outputs, and efficiency of photovoltaic devices depend on climatic parameters $[8,9]$. Within the scope of this study, it was intended to determine time dependent power performances and power values that can be generated under different loads of monocrystalline and polycrystalline solar panels having a rated power of $100 \mathrm{~W}$ by determining total and direct radiation and ambient temperature values for Bursa, Turkey.

\section{Materials and Methods}

In this study, the power performance of monocrystalline and polycrystalline panels experiments was performed under outdoor meteorological conditions of field laboratory of Department of Biosystems Engineering, Faculty of Agriculture, Bursa, Turkey $\left(40^{\circ} 15^{\prime} \mathrm{N}, 28^{\circ} 53^{\prime} \mathrm{E}\right)$. A schematic view and photographs of this apparatus are shown in Figures 1 and 2, respectively. The experiments were conducted from August 19 to August 25, 2014, from 07:00 to 20:00 h. The apparatus was placed far from the shade of trees or buildings during the whole duration of the experiment.

In the testing system, there are monocrystalline $(80 \times$ $98 \mathrm{~cm})$ and polycrystalline $(67 \times 100 \mathrm{~cm})$ solar panels with a power of $100 \mathrm{~W}$. Switch number 1 activates the monocrystalline solar panel (YLE100, Turkwatt, Turkey), and switch number 2 activates the polycrystalline solar panel (TW45P, Turkwatt, Turkey). Due to the design of the system, it is not possible to activate both panels at the same time. There are 10 load levels on the system showing resistance feature. Each generates a resistance of $10 \mathrm{~W}$. The generated load (resistance) amount is able to be adjusted by an 11-graded switch. Thus, the system is able to be fed with a load in between $10 \mathrm{~W}$ and $100 \mathrm{~W}$. The 11th grade of the switches was designed

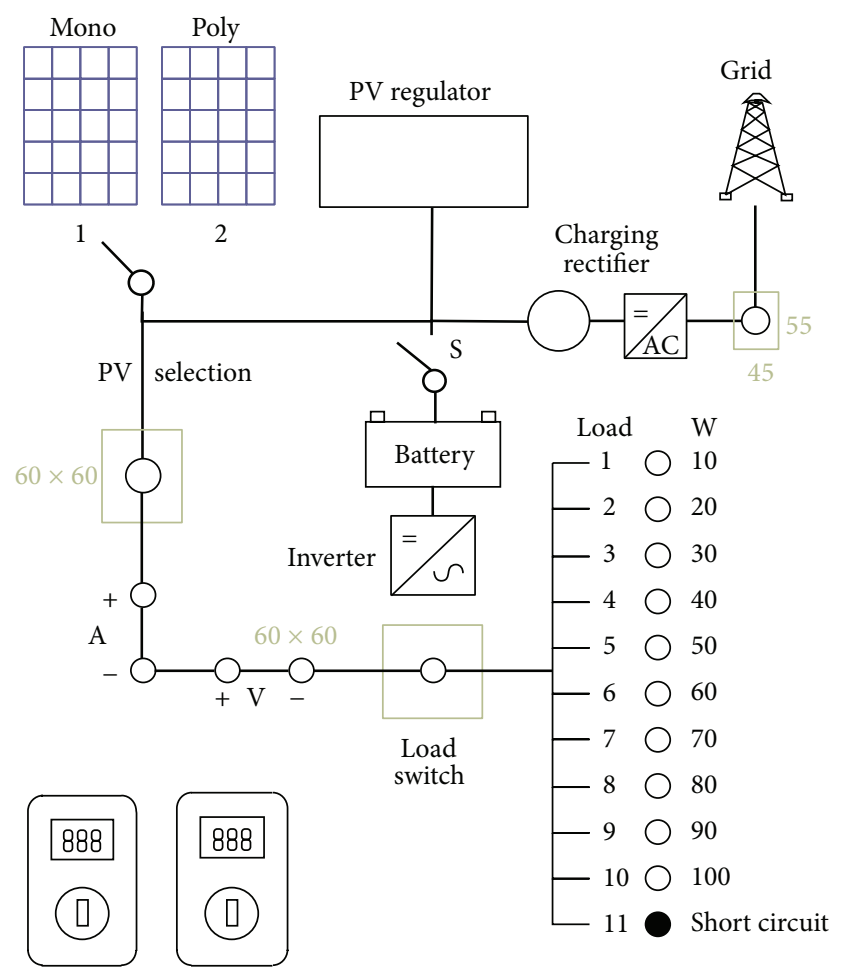

FIgURE 1: Schematic view.

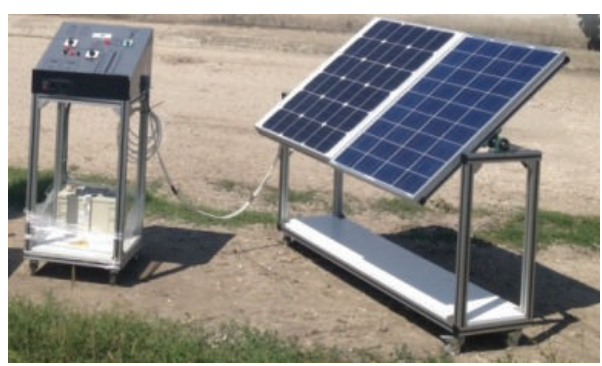

FIgURE 2: Photograph of apparatus.

as short circuit. Within the scope of the study, electrical measurement system consisting of voltmeter (UT60E, UNIT, China) and amperemeter (UT60E, UNI-T, China) was used in the determination of the current, voltage, and power values generated by the solar panels.

The measured climatic data used in this study were recorded by the datalogger (Cr1000, Campell Scientific, USA). The dataset consists of $1 \mathrm{~min}$ averaged measurements of total radiation (CM11 pyranometer, Kipp\&Zonen, Netherlands), direct radiation (CHP1 pyrheliometer, Kipp\&Zonen, Netherlands), and ambient temperature (41342, Young, USA). All instruments as shown in Figure 3 were used with their original calibration factors.

The latitude of the solar panels and their inclination angle with the surface affects the generated energy amounts. In order to obtain electric energy from the solar panel systems in the most efficient manner, the panels should be positioned to be perpendicular to sunlight and to face south $[10,11]$. 


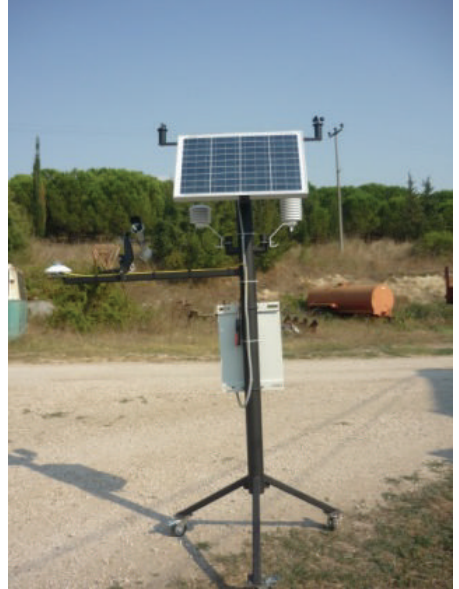

Figure 3: Climatic station.

In respect of angular relations in between solar radiation and Earth, the most significant angle is the declination angle. It is also defined as the angle in between the solar radiation and equatorial plane at 12:00 o'clock. It arises due to the angle of $23^{\circ} 45$ in between the axis of the world and its orbital plane. If the world sun direction is at north of the equatorial plane, the declination angle is deemed as positive. The approximate value of declination angle $(\delta)$ can be calculated by the Cooper equation [12]. In the equation, $n$ is the number of days of the year:

$$
\delta=23,34 \cdot \sin \left(360 \cdot \frac{n+284}{365}\right) .
$$

Using tracking systems is the best way to collect maximum daily energy. This mechanical device follows the direction of the sun all day. The trackers are expensive, need energy for operation, and are not always applicable. Therefore, it is often practicable to orient the solar panel at an optimum tilt angle, $\beta[13]$, where $\Phi$ is the latitude:

$$
\beta=\Phi-\delta
$$

And efficiency is the expression of how much the solar panel is able to convert the solar radiation to useful energy. In the study, considering the solar radiation data measured by pyranometer, the radiation values reaching the solar panel are determined. These values are addressed as radiation reaching the unit surface area at unit time, and they are presented as power. Considering the power values generated by solar panels and measured by the data measurement systems, the efficiency of solar panels may be determined by the equation. In here $\eta$ symbolizes the efficiency (\%), $P$ symbolizes the average power output (W), $H$ symbolizes the total solar radiation $\left(\mathrm{W} / \mathrm{m}^{2}\right)$, and $\mathrm{PV}$ symbolizes the surface area $\left(\mathrm{m}^{2}\right)$ [14]:

$$
\eta=\frac{P}{\mathrm{PV} \cdot H} \times 100 .
$$

And, statistically, a multivariate correlations analysis was performed to evaluate any significant differences on the energy production between total radiation, direct radiation, and ambient temperature. All calculations were carried out using the software JMP (version 7.0, NC, USA).

\section{Results and Discussion}

Within the scope of this study, time dependent power performances and power values of monocrystalline and polycrystalline solar panels under different loads were intended by determining total and direct radiation and temperature values for Bursa, Turkey. The optimal tilt angle of solar panels used within this scope was adjusted to be $27^{\circ}$, and they were positioned to face south. Similar analyses were made to choose optimal tilt angle for the solar panel in order to collect the maximum solar radiation in Madinah, Saudi Arabia. It was found that the loss in the amount of collected energy when using the yearly average fixed angle is around $8 \%$ compared with the monthly optimum tilt angle [13].

Figures 4(a)-4(h) show the daily and average climatic results obtained from the study of the hourly values in the area of Bursa, Turkey. Based on the average results in Figure $4(\mathrm{~h})$ one can conclude that the average ratio of total radiation during the experimental week is around $495.34 \mathrm{~W} / \mathrm{m}^{2}$; that the average ratio of direct radiation during the experimental week is around $541.61 \mathrm{~W} / \mathrm{m}^{2}$; that the ambient temperature during the experimental week is around $27.75^{\circ} \mathrm{C}$. At 13:00, it reached the highest average total radiance by $886.09 \mathrm{~W} / \mathrm{m}^{2}$ and highest average direct normal irradiance by $764.34 \mathrm{~W} / \mathrm{m}^{2}$.

In the tests performed in between 07:00 and 20:00, the highest total radiation had been realized by $1001.13 \mathrm{~W} / \mathrm{m}^{2}$ on 19.08.2014 at 13:00, and direct radiation had been $825.6 \mathrm{~W} / \mathrm{m}^{2}$ at that time, and instantaneous power generation of $87.14 \mathrm{~W}$ had been realized by the monocrystalline panel and of $80.17 \mathrm{~W}$ had been realized by the polycrystalline panel. Within this frame, it was determined that monocrystalline solar panel generates $6.93 \mathrm{~W}$ more instantaneous power than the polycrystalline solar panel (Figure 5(a)).

And the highest power values that the monocrystalline and polycrystalline solar panels are able to generate under different loads are as follows. During the testing period of monocrystalline solar panel, $13.56 \mathrm{~W}$ power was obtained under $10 \mathrm{~W}$ load, $26.97 \mathrm{~W}$ power was obtained under $20 \mathrm{~W}$ load, $39.56 \mathrm{~W}$ power was obtained under $30 \mathrm{~W}$ load, $53.39 \mathrm{~W}$ power was obtained under $40 \mathrm{~W}$ load, $62.17 \mathrm{~W}$ power was obtained under $50 \mathrm{~W}$ load, $74.6 \mathrm{~W}$ power was obtained under $60 \mathrm{~W}$ load, $85.7 \mathrm{~W}$ power was obtained under $70 \mathrm{~W}$ load, $87.14 \mathrm{~W}$ power was obtained under $80 \mathrm{~W}$ load, $79.14 \mathrm{~W}$ power was obtained under $90 \mathrm{~W}$ load, $76.7 \mathrm{~W}$ power was obtained under $100 \mathrm{~W}$ load, and $7.09 \mathrm{~W}$ power was obtained as highest under short circuit. During the testing period of polycrystalline solar panel, $13.39 \mathrm{~W}$ power was obtained under $10 \mathrm{~W}$ load, $27.93 \mathrm{~W}$ power was obtained under $20 \mathrm{~W}$ load, $38.55 \mathrm{~W}$ power was obtained under $30 \mathrm{~W}$ load, $47.93 \mathrm{~W}$ power was obtained under $40 \mathrm{~W}$ load, $60.31 \mathrm{~W}$ power was obtained under $50 \mathrm{~W}$ load, $75.38 \mathrm{~W}$ power was obtained under $60 \mathrm{~W}$ load, $79.55 \mathrm{~W}$ power was obtained under $70 \mathrm{~W}$ load, $80.17 \mathrm{~W}$ power was obtained under $80 \mathrm{~W}$ load, $72.02 \mathrm{~W}$ power was obtained under $90 \mathrm{~W}$ load, $57.4 \mathrm{~W}$ power was 


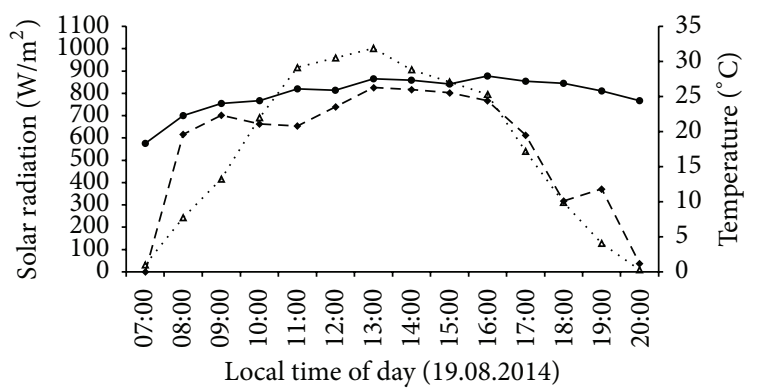

«.. Total radiation $\rightarrow$ Ambient temperature - - Direct radiation

(a)

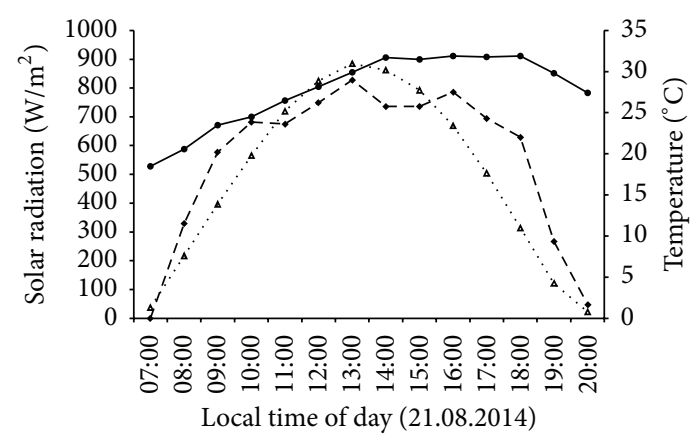

$\therefore$.. Total radiation $\rightarrow$ Ambient temperature - - Direct radiation

(c)

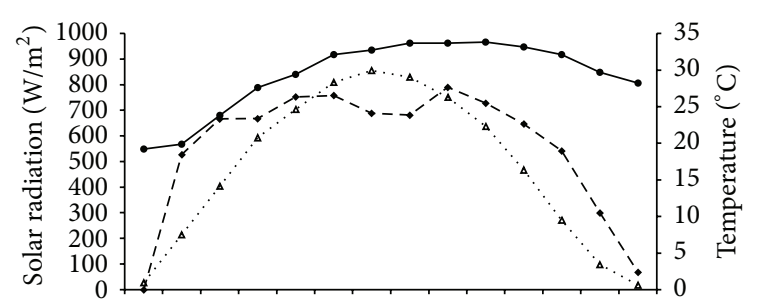

ọ o o o o o o o o o o o o o o

Local time of day (23.08.2014)

.... Total radiation

- - Direct radiation

$\rightarrow$ Ambient temperature

(e)

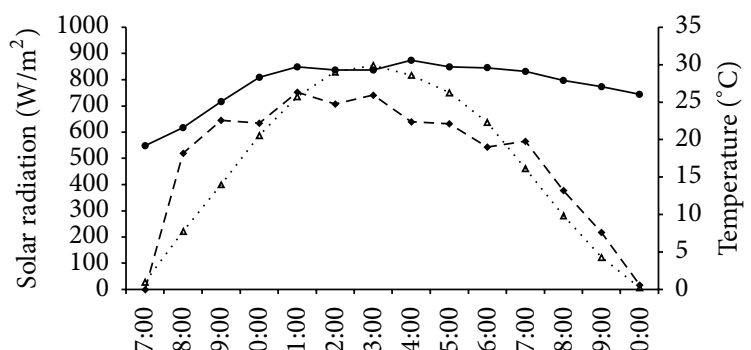

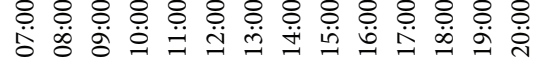
Local time of day (25.08.2014)

... Total radiation $\rightarrow$ Ambient temperature
- Direct radiation

(g)

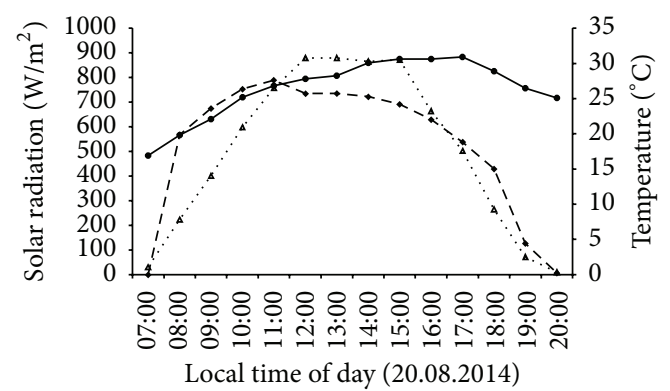

.... Total radiation $\quad \rightarrow$ Ambient temperature - - Direct radiation

(b)

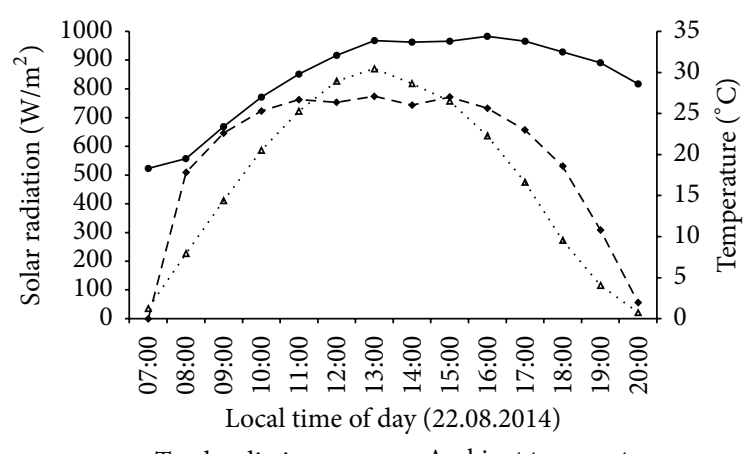

... Total radiation $\rightarrow$ Ambient temperature - - Direct radiation

(d)

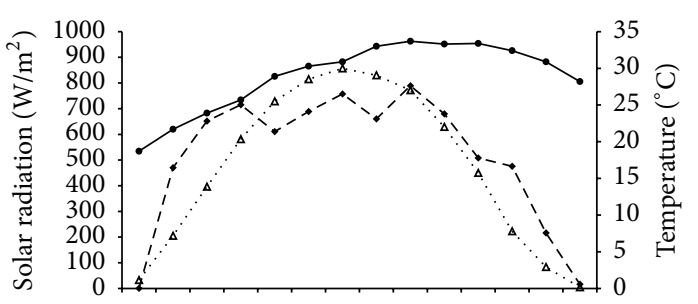

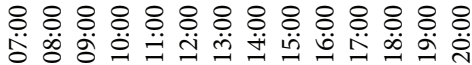
Local time of day (24.08.2014)

.... Total radiation $\rightarrow$ Ambient temperature

- - Direct radiation

(f)

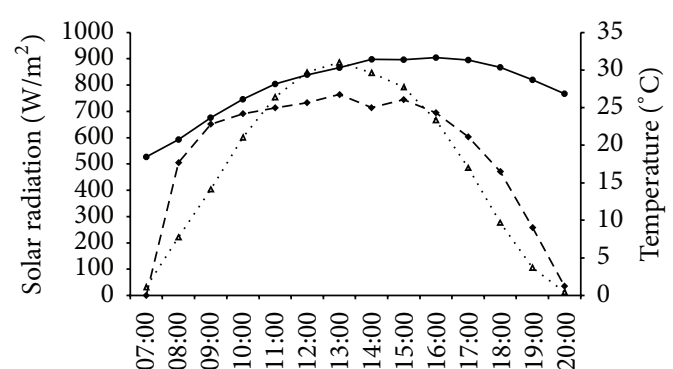

Local time of day

$\cdots$... Total radiation $\quad \rightarrow$ Ambient temperature

- - Direct radiation

(h)

FIGURE 4: Daily and average results of climatic conditions. 

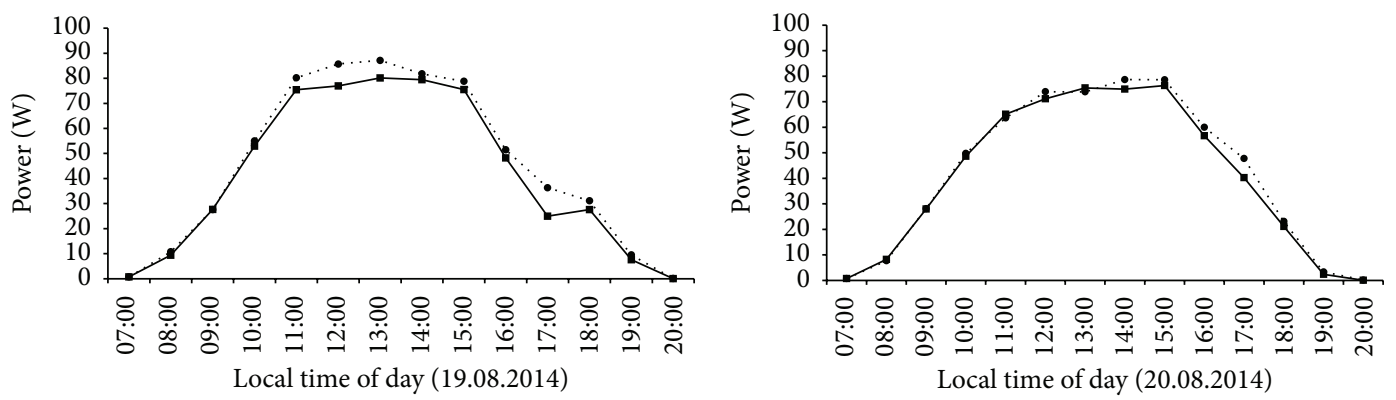

... Monocrystalline

(a)

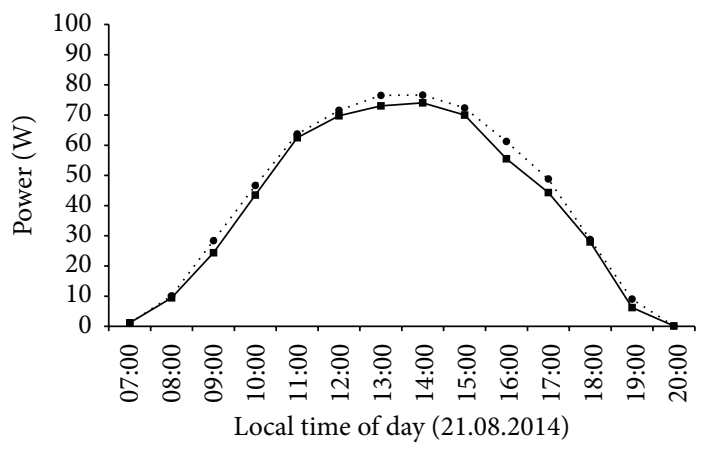

.... Monocrystalline

$\rightarrow$ Polycrystalline

(c)

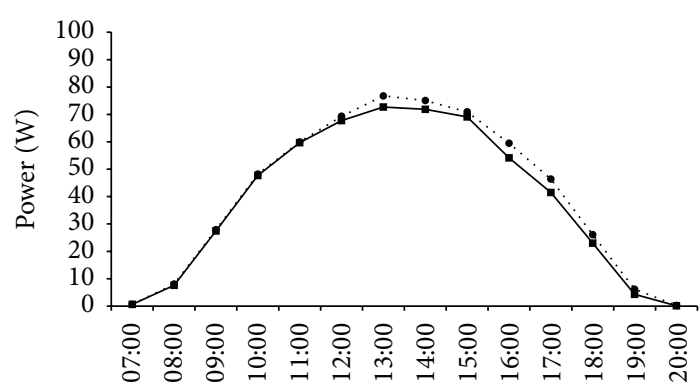

Local time of day (23.08.2014)

-... Monocrystalline

$\rightarrow$ Polycrystalline

(e)

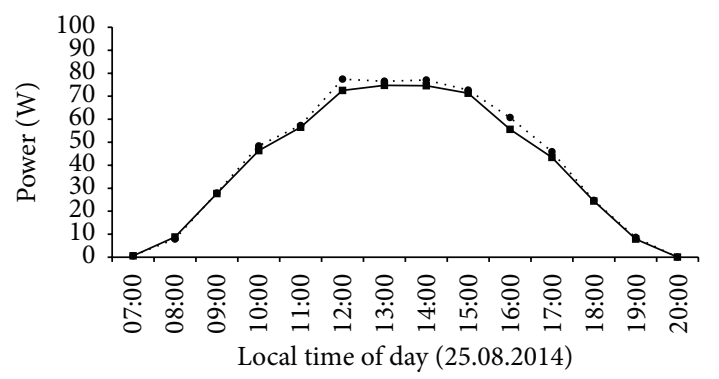

-.. Monocrystalline

$\rightarrow$ Polycrystalline

(g)
... Monocrystalline
$\ldots$ Polycrystalline

(b)

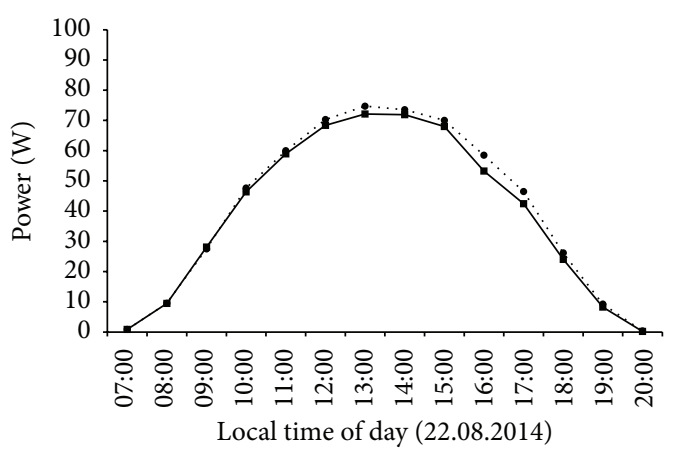

-.. Monocrystalline

$\rightarrow$ Polycrystalline

(d)

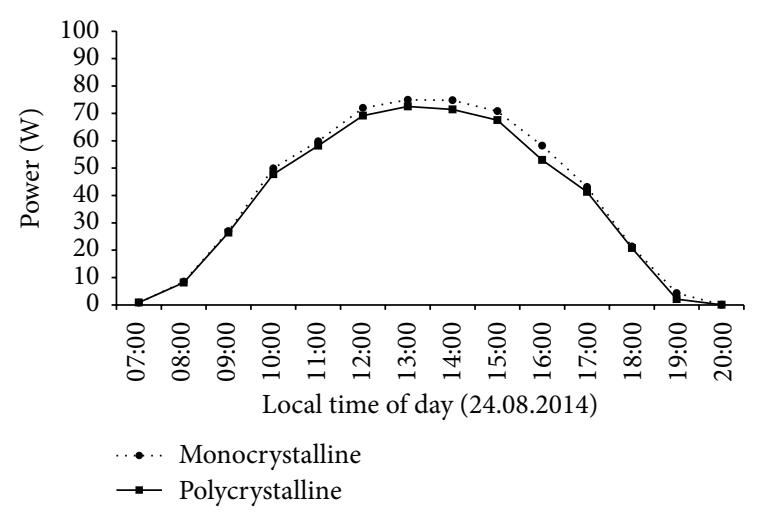

(f)

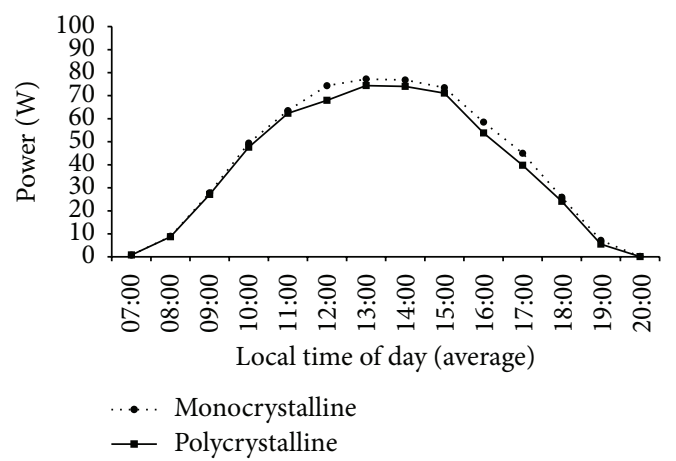

(h)

FIGURE 5: Hourly power output performance. 
TABLE 1: Multivariate correlations coefficients.

\begin{tabular}{|c|c|c|c|c|}
\hline & Direct radiation & Ambient temperature & Monocrystalline solar panel & Polycrystalline solar panel \\
\hline Total radiation & $0,8810^{* *}$ & $0,5255^{* *}$ & $0,9876^{* *}$ & $0,9832^{* *}$ \\
\hline Direct radiation & & $0,4986^{* *}$ & $0,8442^{* *}$ & $0,8439^{* *}$ \\
\hline Ambient temperature & & & $0,5940^{* *}$ & $0,5881^{* *}$ \\
\hline Monocrystalline solar panel & & & & $0,9938^{* *}$ \\
\hline
\end{tabular}

** shows the high level of importance statistically.

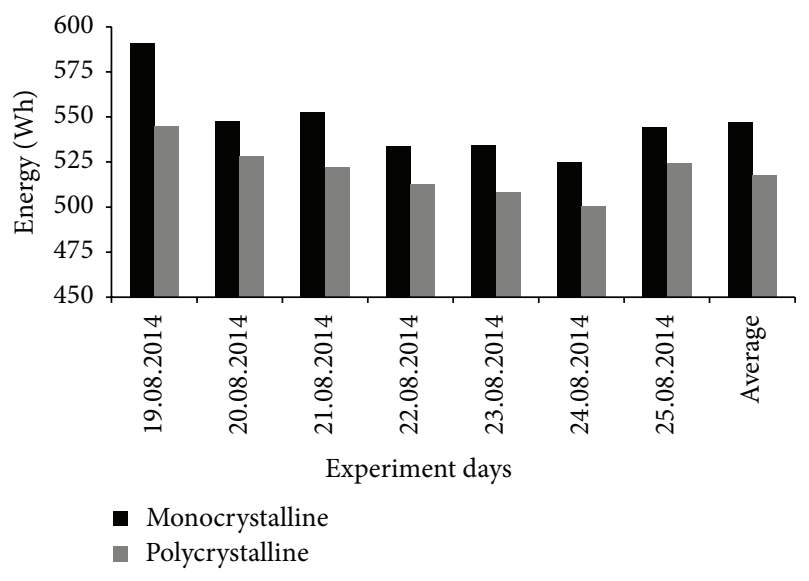

FIGURE 6: Energy output performance.

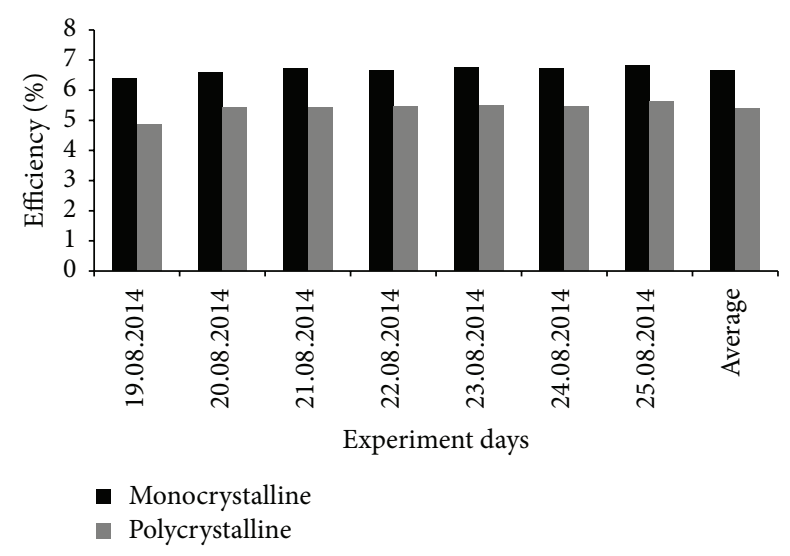

FIgURE 7: Panels efficiencies ratio.

obtained under $100 \mathrm{~W}$ load, and $6.3 \mathrm{~W}$ power was obtained under short circuit.

Figure 6 presents the daily energy production performance of panels. Depending on the radiation intensity to the panel surface differences are observed between energy productions. Average energy performances of monocrystalline and polycrystalline are $546.82 \mathrm{Wh}$ and $517.52 \mathrm{Wh}$, respectively. Maximum and mininum energy production from panels were actualized on 19.08.2014 and 24.08.2014, respectively. The results obtained from the measurement show that monocrystalline solar panel performed better compared to polycrystalline at every experiment day.

Figure 7 shows the bar graph for daily module efficiency for each type of solar panel in this experiment.
The average conversion efficiencies of monocrystalline and polycrystalline arrays are $6.65 \%$ and $5.38 \%$, respectively. It can be seen that highest monocrystalline module efficiency in day $7(6.82 \%)$ and lowest in day 1 (6.39\%) show a significantly higher efficiency compared to polycrystalline, which is $1.21 \%$ and $1.52 \%$, respectively. A similar panel efficiency was found to be $11.02 \%$ and $4.32 \%$ for the Solarex photovoltaic monocrystalline and polycrystalline panels, respectively [15]. Power performances of solar panels in Singapore are presented by Jiang and Wong, who found a maximum efficiency of $8.12 \%$ for the monocrystalline panel and 7.45\% for polycrystalline panel [16]. Also, average efficiencies of the monocrystalline and polycrystalline photovoltaic panels in Brasil were found to be $9.40 \%$ and $6.57 \%$, respectively [5]. However, some works show the polycrystalline panels with a better performance, such as Ghazali and Abdul Rahman who show that polycrystalline panel is higher power output compared to monocrystalline panel in 4-day period with efficiency of $7.97 \%$ (day 1), 3.49\% (day 2), $2.41 \%$ (day 3), and $7.52 \%$ (day 4) [14]. Considering the previous studies, more researches must be done in order to determine which specific conditions cause each kind of panel to perform better. From this experiment, it can be concluded that monocrystalline solar panels are the most suitable type of photovoltaic module to be used under Bursa, Turkey, climate condition.

The correlation coefficients relevant to the examined features are given in Table 1. According to the obtained findings, very high significant relation in positive direction was found in between total radiation and energy generation from monocrystalline and polycrystalline panel. High significant relation in positive direction was found in between direct radiation and energy generation from monocrystalline and polycrystalline panel. Also, there was a statistically midsignificant relation in positive direction between ambient temperature and energy generation from monocrystalline and polycrystalline panel.

\section{Conclusion}

Developing a clean and renewable energy helps energy independence in Turkey. Solar energy with the types of polycrystalline and monocrystalline panels is most commonly used with different characteristic and efficiency. In this study, it has been shown that the efficiency of photovoltaic panels is influenced by climate conditions, type of used solar cells, and so forth. The daily average photovoltaic panel efficiency was $6.65 \%$ and $5.38 \%$ for the monocrystalline and polycrystalline, respectively. More researches must be done in order to determine which specific conditions cause each kind 
of panel to perform better. This paper would be useful for the photovoltaic panel manufactures, researchers, and generating members to decide for Bursa, Turkey.

\section{Competing Interests}

The authors declare that there are no competing interests regarding the publication of this paper.

\section{Acknowledgments}

This study was done with the financial support of the Project no. Z-2013/31 approved by the Scientific Research Project Unit of Uludag University.

\section{References}

[1] V. Ar1, Energy sources, energy planning and energy strategies of Turkey [M.S. thesis], Department of Mining Engineering, Institute of Natural and Applied Sciences, University of Cukurova, Adana, Turkey, 2007.

[2] Usage Areas of Energy, 2014, http://enerjisistemleri.blogspot .com.tr/2010/12/resim-galerisi.html.

[3] H. H. Öztürk and D. Kaya, Electricity Generation from Solar Energy: Photovoltaic Technology, Umuttepe Publications, Kocaeli, Turkey, 2013.

[4] B. Parida, S. Iniyan, and R. Goic, "A review of solar photovoltaic technologies," Renewable and Sustainable Energy Reviews, vol. 15, no. 3, pp. 1625-1636, 2011.

[5] C. E. C. Nogueira, J. Bedin, R. K. Niedzialkoski, S. N. M. de Souza, and J. C. M. das Neves, "Performance of monocrystalline and polycrystalline solar panels in a water pumping system in Brazil," Renewable and Sustainable Energy Reviews, vol. 51, pp. 1610-1616, 2015.

[6] A. I. Ismael, Electrical energy analyses in monocristal of solar cell systems [M.S. thesis], Gazi University Institute of Science and Technology, Ankara, Turkey, 2012.

[7] Q. Kou, A method for estimation the long-term performance of photovoltaic pumping system [M.S. thesis], The University of Wisconsin-Madison, Solar Energy Laboratory, Madison, Wis, USA, 1996.

[8] J. Carstensen, G. Popkirov, J. Bahr, and H. Föll, "CELLO: an advanced LBIC measurement technique for solar cell local characterization," Solar Energy Materials and Solar Cells, vol. 76, no. 4, pp. 599-611, 2003.

[9] D. H. W. Li, G. H. W. Cheung, and J. C. Lam, "Analysis of the operational performance and efficiency characteristic for photovoltaic system in Hong Kong," Energy Conversion and Management, vol. 46, no. 7-8, pp. 1107-1118, 2005.

[10] S. Turhan and I. Çetiner, "Performance evaluation of photovoltaic systems," in Proceedings of the National Roof \& Wall Symposium, vol. 6, Bursa, Turkey, 2012.

[11] A. Özgöçmen, Electricity generation using solar cells [M.S. thesis], Gazi University, Institute of Science and Technology, Ankara, Turkey, 2007.

[12] D. S. Strebkov, A. E. Irodionov, V. P. Tarasov, and E. G. Bazarova, "Optimum orientation of a nontracking solar concentrator," Thermal Engineering, vol. 55, no. 12, pp. 997-1000, 2008.

[13] M. Benghanem, "Optimization of tilt angle for solar panel: case study for Madinah, Saudi Arabia," Applied Energy, vol. 88, no. 4, pp. 1427-1433, 2011.
[14] M. A. Ghazali and A. M. Abdul Rahman, "The performance of three different solar panels for solar electricity applying solar tracking device under the Malaysian climate condition," Energy and Environment Research, vol. 2, no. 1, pp. 235-243, 2012.

[15] U. Stutenbaeumer and B. Mesfin, "Equivalent model of monocrystalline, polycrystalline and amorphous silicon solar cells," Renewable Energy, vol. 18, no. 4, pp. 501-512, 1999.

[16] F. Jiang and A. Wong, "Study on the performance of different types of PV modules in Singapore," in Proceedings of the 7th International Power Engineering Conference (IPEC '05), pp. 1109, Singapore, December 2005. 

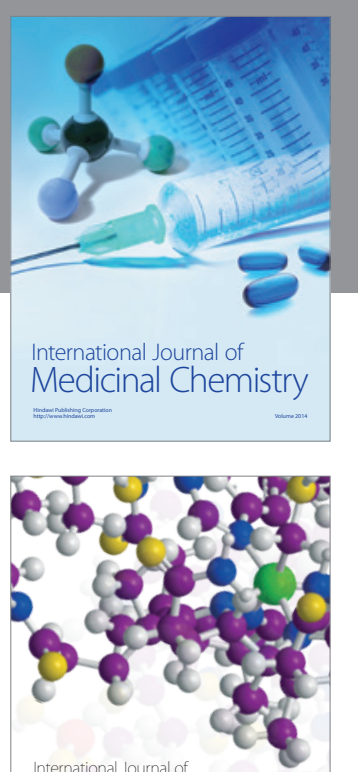

Carbohydrate Chemistry

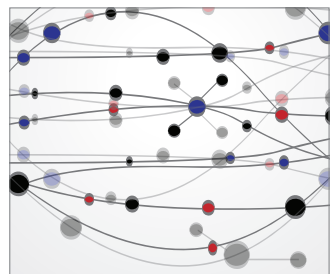

The Scientific World Journal
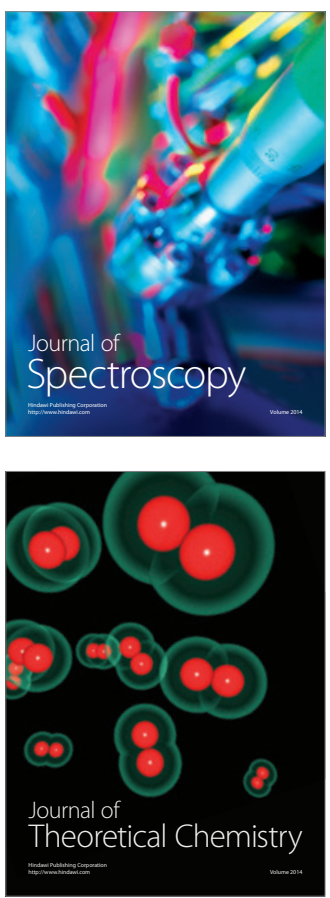
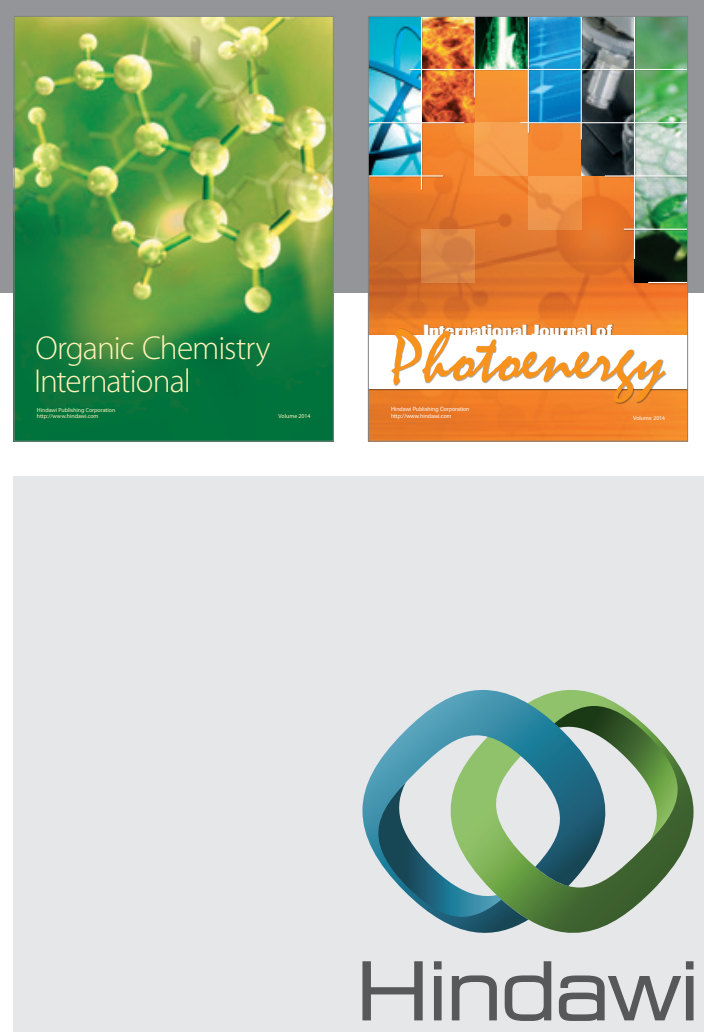

Submit your manuscripts at

http://www.hindawi.com

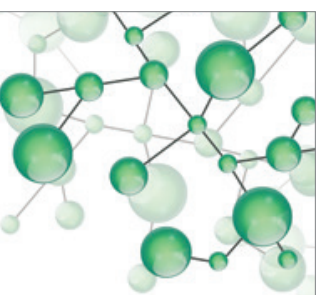

International Journal of

Inorganic Chemistry

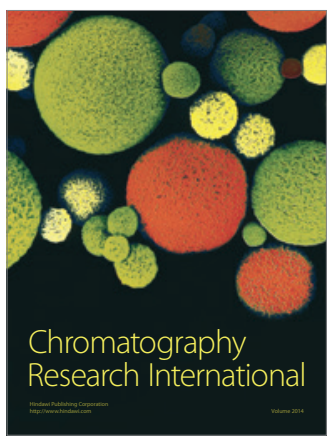

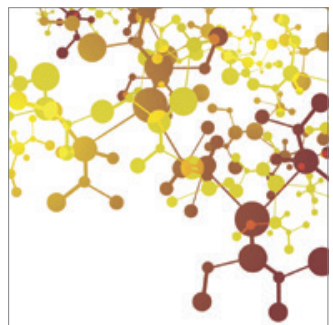

Applied Chemistry
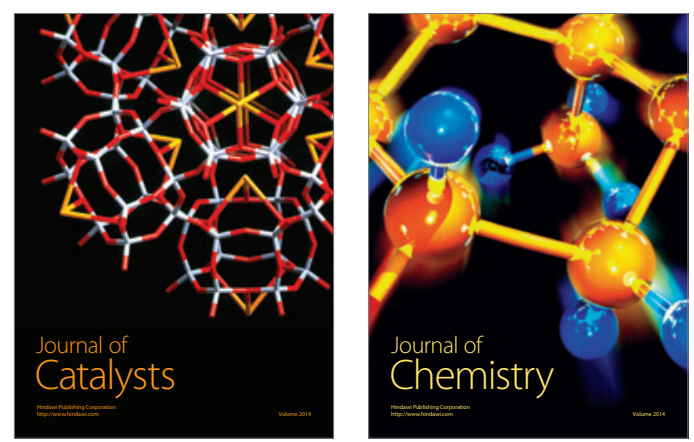
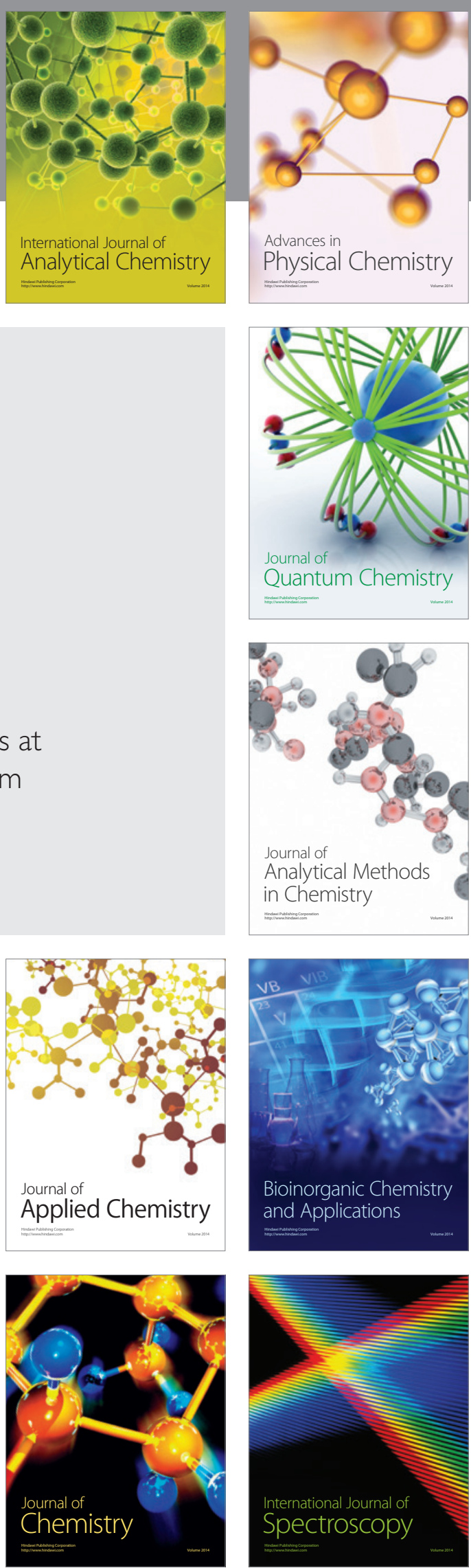